Handbook of Citizen Science in Conservation and Ecology 
The publisher gratefully acknowledges the generous contribution to this book provided by the International Community Foundation/JiJi Foundation Fund. 


\section{Handbook of Citizen Science in Conservation and Ecology}

Edited by CHRISTOPHER A. LEPCZYK, OWEN D. BOYLE, and TIMOTHY L. V. VARGO

Foreword by Reed F. Noss

甲

UNIVERSITY OF CALIFORNIA PRESS 
University of California Press

Oakland, California

(C) 2020 by the Regents of the University of California

Library of Congress Cataloging-in-Publication Data

Names: Lepczyk, Christopher A. (Christopher Andrew), I970- editor. | Boyle, Owen D., I974- editor. | Vargo, Timothy L. V., I973- editor. | Noss, Reed F., writer of supplementary textual content.

Title: Handbook of citizen science in ecology and conservation / edited by Christopher A. Lepczyk, Owen D. Boyle, and Timothy L. V. Vargo ; foreword by Reed F. Noss.

Description: Oakland, California : University of California Press, [2020]| Includes bibliographical references and index.

Identifiers: LCCN 2019042776 (print) | LCCN 2019042777 (ebook) | ISBN 9780520284777 (cloth) | ISBN 978052028479 I (paperback) | ISBN 9780520960473 (ebook)

Subjects: LCSH: Conservation of natural resources-Citizen participation-Handbooks, manuals, etc. | Ecology-Handbooks, manuals, etc.

Classification: LCC s944.5.C57 H36 2020 (print) | LCC s944.5.C57 (ebook) | DDC 639.9-dc23

LC record available at https://lccn.loc.gov/2019042776

LC ebook record available at https://lccn.loc.gov/2019042777

Manufactured in the United States of America
$\begin{array}{lllllllll}28 & 27 & 26 & 25 & 24 & 23 & 22 & 21 & 20\end{array}$
I0 $9 \begin{array}{lllllllll}9 & 8 & 7 & 6 & 5 & 4 & 3 & 2 & \text { I }\end{array}$ 
To the citizen scientists of the past, present, and future 
